\title{
The levels of the plasma coagulation factors after trauma and childbirth
}

\author{
E. DAVIDSON AND S. TOMLIN \\ From the Department of Medicine, University of Cambridge
}

SYNOPSIS The levels of the plasma coagulation factors are raised in the post-traumatic and postpartum periods. Factors I, VIII, IX, and X were raised in two groups, one of patients after trauma, ${ }_{i}$ the other of patients after childbirth, while factors V and VII were raised in the puerperal group: only. The relationship between these changes and thrombosis in vivo is discussed.

Thrombosis is generally attributed to a combination of factors summarized in the classical triad of Virchow but a detailed examination of this triad in relation to venous thrombosis shows that there is little evidence of an intimal lesion (Douglas, 1962). Although stasis can be demonstrated with specialized techniques (McLachlin, McLachlin, Jory, and Rawling, 1960), the extensive studies of Wessler (1955) and of Wessler, Freiman, Reimer, and Thomas (1961) on experimental serum-induced thrombosis suggest that retarded blood flow determines only the site of thrombosis when a hypercoagulable state is induced. Evidence of a hypercoagulable state in thrombo-embolic disease in man is based largely on the increase in the platelet and fibrinogen levels. Coagulation tests which measure overall activity are of limited value in demonstrating a potentiated clotting mechanism (Ingram, Biggs, and Armitage, 1953; Douglas, 1962). This study presents additional evidence of an increase in the levels of the plasma coagulation factors after trauma (Egeberg, 1962) and childbirth (Alexander, 1962).

\section{MATERIALS AND METHODS}

TRAUMATIC GROUP Twenty-one bedridden orthopaedic patients were bled 10 to 20 days after sustaining a fracture of a long bone.

PUERPERAL GROUP Forty-three obstetrical patients were bled seven to 10 days after an uncomplicated normal delivery.

CONTROL GROUPS Normal hospital and laboratory staff were matched for age and sex and tested simultaneously with the comparable group.

Recejved for publication 17 October 1962.
PROCEDURE Blood was collected by clean venepunctureo into paraffined syringes and stored at $4^{\circ} \mathrm{C}$. in siliconized $\bar{\rho}$ tubes containing $20 \%$ trisodium citrate per $5 \mathrm{ml}$. blood. The assays of fibrinolysis were completed within fouro hours while the maximum delay in assaying factors $V \omega$ and VIII was 12 hours. The remaining tests were carriedర out on platelet-free plasma stored at $-20^{\circ} \mathrm{C}$. for periods up to six weeks.

COAGULATION TESTS The methods in general use are those recommended by Biggs and Macfarlane (1962). The following assay techniques were used: For factor $\mathrm{I} \overline{\mathrm{O}}$ (fibrinogen), tyrosine method (Holburn, 1955); for factor 3 II (prothrombin), two-stage area method (Biggs and Douglas, 1953); for factor V, oxalate plasma incubated at? $37^{\circ} \mathrm{C}$. for 24 hours (Wolf, 1953); for factors VII-X bentonite and alumina plasmas (Hougie, 1962); for? factor VIII (A.H.G.), stored haemophiliac A plasma윽 (Pitney, 1956); for factor IX (Christmas), stored haemophiliac B serum (Bolton and Clarke, 1959); and forô factor X (Stuart-Prower), bentonite and alumina plasmas with R.V.V. cephalin reagent (Hougie, 1962).

Fibrinolysis was defined as whole blood clot lysis (Fearnley, Balmforth, and Fearnley, 1957). The amounto of lysis present at three hours was determined by removing the unlysed clot and expressing the residual $\mathrm{Hb}$ as aO percentage of the total $\mathrm{Hb}$.

Throughout the study one of us acted as the $100 \%$ normal in the assay tests.

\section{RESULTS}

The results presented in Table I show a significant 0 rise $(P=0.05)$ of factors $I$, VIII, IX, and X in botho the puerperal and traumatic groups. Factors $V$ and $\vec{\Phi}$ VII were raised in the puerperal group only while the lysis of whole blood was diminished in the traumatic group. 
The levels of the plasma coagulation factors after trauma and childbirth

TABLE I

\begin{tabular}{|c|c|c|c|c|c|c|}
\hline Factor & $\begin{array}{l}\text { Puerperal } \\
\text { Group } \\
(\% \pm \text { S.D. })\end{array}$ & $\begin{array}{l}\text { LEVELS OF PLASMA } \\
\text { Controls } \\
(\% \pm S . D .)\end{array}$ & $\begin{array}{l}\text { COAGULATION } \\
\text { Significance of } \\
\text { Difference }\end{array}$ & $\begin{array}{l}\text { FACTORS IN TWO } \\
\text { Traumatic } \\
\text { Group } \\
(\% \pm \text { S.D. })\end{array}$ & $\begin{array}{l}\text { GROUPS } \\
\text { Controls } \\
(\% \pm S . D .)\end{array}$ & $\begin{array}{l}\text { Significance of } \\
\text { Difference }\end{array}$ \\
\hline I & $\begin{array}{r}337.0 \\
\pm 96.4\end{array}$ & $\begin{array}{r}171 \cdot 1 \\
\pm 87 \cdot 6\end{array}$ & $p<0.003$ & $\begin{array}{r}371 \cdot 3 \\
\pm 128 \cdot 2\end{array}$ & $\begin{array}{r}227 \cdot 2 \\
\pm 88 \cdot 0\end{array}$ & $p<0.003$ \\
\hline II & $\begin{array}{r}79 \cdot 7 \\
\pm 27 \cdot 9\end{array}$ & $\begin{array}{r}80.1 \\
\pm 18.7\end{array}$ & Not significant & $\begin{array}{r}69 \cdot 3 \\
\pm 16 \cdot 8\end{array}$ & $\begin{array}{r}81 \cdot 0 \\
\pm 23 \cdot 1\end{array}$ & Not significant \\
\hline V & $\begin{array}{r}157 \cdot 3 \\
\pm 79 \cdot 1\end{array}$ & $\begin{array}{r}112.1 \\
\pm 35.9\end{array}$ & $\mathrm{p}<0.003$ & $\begin{array}{r}140 \cdot 4 \\
\pm 70 \cdot 3\end{array}$ & $\begin{array}{r}132 \cdot 7 \\
\pm 91 \cdot 3\end{array}$ & Not significant \\
\hline VII-X & $\begin{array}{r}262.4 \\
\pm 165.4\end{array}$ & $\begin{array}{r}122.1 \\
\pm 38.7\end{array}$ & $\mathrm{p}<0.003$ & $\begin{array}{r}115 \cdot 2 \\
\pm 35 \cdot 0\end{array}$ & $\begin{array}{r}104 \cdot 8 \\
\pm 24 \cdot 8\end{array}$ & Not significant \\
\hline VIII & $\begin{array}{r}135 \cdot 2 \\
\pm 48 \cdot 2\end{array}$ & $\begin{array}{r}97.5 \\
\pm 28.7\end{array}$ & $\mathrm{p}<0.003$ & $\begin{array}{r}131.0 \\
\pm 35.6\end{array}$ & $\begin{array}{r}87.5 \\
\pm 18.7\end{array}$ & $p<0.003$ \\
\hline IX & $\begin{array}{r}112.5 \\
\pm 60.2\end{array}$ & $\begin{array}{r}69 \cdot 6 \\
\pm 42.8\end{array}$ & $\mathrm{p}<0.003$ & $\begin{array}{r}136 \cdot 4 \\
\pm 70 \cdot 6\end{array}$ & $\begin{array}{r}81.0 \\
\pm 57.2\end{array}$ & $p<0.0125$ \\
\hline $\mathbf{x}$ & $\begin{array}{r}152.4 \\
\pm 62.8\end{array}$ & $\begin{array}{r}107 \cdot 4 \\
\pm 48 \cdot 1\end{array}$ & $\mathrm{p}<0.003$ & $\begin{array}{r}133.5 \\
\pm 50 \cdot 3\end{array}$ & $\begin{array}{r}106.4 \\
\pm 51.5\end{array}$ & $p<0.05$ \\
\hline Lysis & $\begin{array}{r}65 \cdot 8 \\
+27 \cdot 1\end{array}$ & $\begin{array}{r}73 \cdot 3 \\
\pm 22 \cdot 2\end{array}$ & Not significant & $\begin{array}{r}45.8 \\
\pm 24.8\end{array}$ & $\begin{array}{r}71.4 \\
\pm 25.5\end{array}$ & $p<0.003$ \\
\hline
\end{tabular}

\section{DISCUSSION}

The results are similar to previous reports of raised plasma coagulation factors in the latter part of pregnancy and the puerperium. Increases are reported in factor I (Dieckmann and Wegner, 1934; Ratnoff and Holland, 1959), factor VII-X (Loeliger and Koller, 1952; Alexander, Meyers, Kenny, Goldstein, Gurewich, and Grinspoon, 1956), factor IX (Ratnoff and Holland, 1959), and factor X (Pechet and Alexander, 1961). Contrary to the results of this siudy, factor V (Alexander et al., 1956; Ratnoff and Holland, 1959) and factor VIII (Ratnoff and Holland, 1959) are reported as normal. With one exception (Ratnoff and Holland, 1959) the levels of factor II were found to be normal (Loeliger and Koller, 1952; Alexander et al., 1956).

There are few reports on the effect of trauma on the levels of the plasma coagulation factors. The post-operative period has been studied in detail (Egeberg, 1962) and raised levels of factors I, VIII, IX, X, and XI with normal levels of factors II, V, and VII-X are reported.

A decrease in the fibrinolytic activity has already been reported in the post-operative period (Franz, Kark, and Hathorn, 1961). No credence can be given to the result in the traumatic group as the diminution of fibrinolysis in whole blood clots may reflect the raised levels of fibrinogen (Freiman and Cliffton, 1958).

The accumulated evidence shows an increase in several of the plasma coagulation factors following trauma, operations, and childbirth. These conditions are associated with an increased tendency to venous thrombosis. A similar relationship has been noted experimentally in rats fed on diets which produce venous and arterial thrombosis. These animals develop a striking increase in the levels of the plasma coagulation factors (Davidson, Howard, and Gresham, 1962; Merskey, Wohl, and Oka, 1962; Fisher, Kupfer, and Kagan, 1962). Additional evidence of the importance of the levels of the plasma coagulation factors in thrombosis is derived from the results of anticoagulant treatment. Coumarin and indanedione derivatives, apparently by reducing the levels of factors II, VII, IX, and X, reduce the incidence of thrombo-embolic complications in the post-operative, post-traumatic, and post-partum period (Douglas, 1962). The relationship, however, between tests in vitro of coagulation and thrombosis in vivo is complex. The raised levels of the plasma coagulation factors may represent an effect rather than the cause of thrombosis. Although the patients selected in this study had no clinical evidence of thrombo-embolic complications, they may not represent a 'prethrombotic state', as Sevitt and Gallagher (1959) have emphasized the frequency of silent thrombosis in traumatic disease. On the other hand, in rat experiments the raising of the plasma coagulation factors precedes even the histological evidence of thrombosis (Davidson, Howard, and Gresham, 1961).

Further studies are needed in patients with thrombo-embolic complications. Raised levels of factor VII-X (De Nicola, 1953; Poller, 1959) and factor V (Ingram, 1955) have been reported. 
We are indebted to the Departments of Orthopaedics and Obstetrics for access to clinical material. E.D. carried out this work during the tenure of an Elmore research studentship.

\section{REFERENCES}

Alexander, B., Meyers, L., Kenny, J., Goldstein, R., Gurewich, V., and Grinspoon, L. (1956). New Engl. J. Med., 254, 358. (1962). Circulation, 25, 872.

Biggs, Rosemary, and Douglas, A. S. (1953). J. clin. Path., 6, 15.

, and Macfarlane, R. G. (1962). Human Blood Coagulation, 3rd ed. Blackwell, Oxford.

Bolton, F. G., and Clarke, J. E. (1959). Brit. J. Haemat., 5, 396.

Davidson, E., Howard, A. N., and Gresham, G. A. (1961). Brit. J. exp. Path. 42, 195.

, - (1962). Ibid., 43, 166.

De Nicola, P. (1953). Blood, 8, 947.

Dieckmann, W. J., and Wegner, C. R. (1934). Arch. intern. Med., 53, 353.

Douglas, A. S. (1962). Anticoagulant Therapy, p. 64. Blackwell, Oxford.

Egeberg, O. (1962). Scand. J. clin. Lab. Invest., 14, 253.

Fearnley, G. R., Balmforth, G., and Fearnley, E. (1957). Clin. Sci., 16, 645 .
Fisher, L. M., Kupfer, H. G., and Kagan, E. (1962). Fed. Proc., 21, No. 2 (Abstracts), p. 59.

Franz, R. C., Kark, A. E., and Hathorn, M. (1961). Lancet, 1, 195. Freiman, A. H., and Cliffton, E. E. (1958). Thrombos. Diathes. Haemorrh. (Stuttg.), 2, 269.

Holburn, R. R. (1955). In The Coagulation of Blood, edited by L. M. Tocantins, p. 155. Grune and Stratton, New York.

Hougie, C. (1962). Proc. Soc. exp. Biol. (N.Y.), 109, 754.

Ingram, G. I. C., Biggs, R., and Armitage, P. (1953). J. clin. Path., 6, 46.

Ingram, I. (1955). In Thrombosis and Embolism: Proc. First int. Conf., Basel, 1954, p. 446.

Loeliger, A., and Koller, F. (1952). Acta haemat. (Basel), 7, 157.

McLachlin, A. D., McLachlin, J. A., Jory, T. A., and Rawling, E. G. (1960). Ann. Surg., 152, 678.

Merskey, C., Wohl, H., and Oka, M. (1962). Fed. Proc., 21, No. 2 (Abstracts), p. 58.

Pechet, L., and Alexander, B. (1961). New Engl. J. Med., 265, 1093. Pitney, W. R. (1956). Brit. J. Haemat., 2, 250.

Poller, L. (1959). J. clin. Path., 12, 331.

Ratnoff, O. D., and Holland, T. R. (1959). Ann. N.Y. Acad. Sci., 75, 626.

Sevitt, S., and Gallagher, N. G. (1959). Lancet, 2, 981.

Wessler, S. (1955). J. clin. Invest., 34, 647.

Freiman, P. G Reimer, S. M and Thomas, P. P. (1961). Conference on Atherosclerosis. N.Y. Heart Assoc., p. 18.

Wolf, P. (1953). J. clin. Path., 6, 34. 